\title{
The Sanità district in Naples: community involvement in developing its heritage value
}

\author{
C. Salomone \\ UFR of Geography and Planning, Lille I University, France
}

\begin{abstract}
Naples is one of the most ancient cities in Europe, located in the centre of the ancient Mediterranean region, and as such has a very rich cultural heritage. Nowadays, the current urban fabric preserves a selection of outstanding elements of its long and eventful history, but we set out to focus attention on this littleknown inner-city community, the Sanità District. Despite the district's rich cultural history and heritage, it is still a marginal touristic player. This workingclass district has been neglected for a long period of time. Since the 1990s, Naples has been experiencing a renaissance. The trend for reviving heritage would be selected through a locally relevant participation process that is appropriate to the context. Many associations are already working to foster an active and competitive heritage process. Local stakeholders must be associated with the mobilization of the inhabitants as with the associative dynamics that have been enacted since the 1980s. This concept is associated with the heritagization process: a Canadian concept from the 2008 Icomos Symposium. This integrates the attitudes that need to be adopted and the approaches and methods that need to be developed to ensure that the spirit of place can be transmitted; that is to say, the process that leads to the recognition of the historic value of certain objects and practices and of the imperative need to ensure they are protected. Our research method therefore is aimed at identifying how the effects of these are being felt by actors, public and private, and local inhabitants and tries to explore their needs, aspirations, fears and concerns by means of direct interviews and surveys. The results of these are focused on local networks and on stakes, objectives and modalities, the levels of success in achieving heritagization outcomes and an assessment of their social impact.

Keywords: heritagization, evaluation policy, involvement of the inhabitants, local development, sustainable tourism.
\end{abstract}




\section{Introduction}

Listed as a world heritage site since 1995, the historical centre of Naples is a complex site owing to its management, its conservation and its activities, as well as a result of its expansion and the density of its diverse, stratified and neglected heritage. La Sanità, a popular and authentic district, belongs to the historical centre and it enjoys a revival of its heritage and tourism through local projects integrating social, cultural, economic and political dimensions.

This paper deals with the role of local communities in "heritagization": here, heritage is viewed as the result of a long social, cultural and economic process [2]. It assumes the ownership, knowledge and recognition by local communities. What are, then, the interrelations between the involvement of the inhabitants, the enhancement of heritage and local development?

\section{The complexity of a district}

This area, situated in the north of the ancient centre, outside the walls, is an easily identified and identifiable territory (Figure 1). Popularised in the collective imagination and incorporated within traditional Naples, it constitutes a particular place in the history of the town [3]. Because of its physical characteristics, it is a relatively individual space and its rich heritage testifies to the length of human occupation. The socio-economic data reflect the difficulties experienced by this deprived, densely populated and popular district dominated by the black market [4]. Violence and delinquency are rife and it is under the influence of the Camorra. Little known, hidden and suffering from a bad image, it is not on the tourist circuits [5].

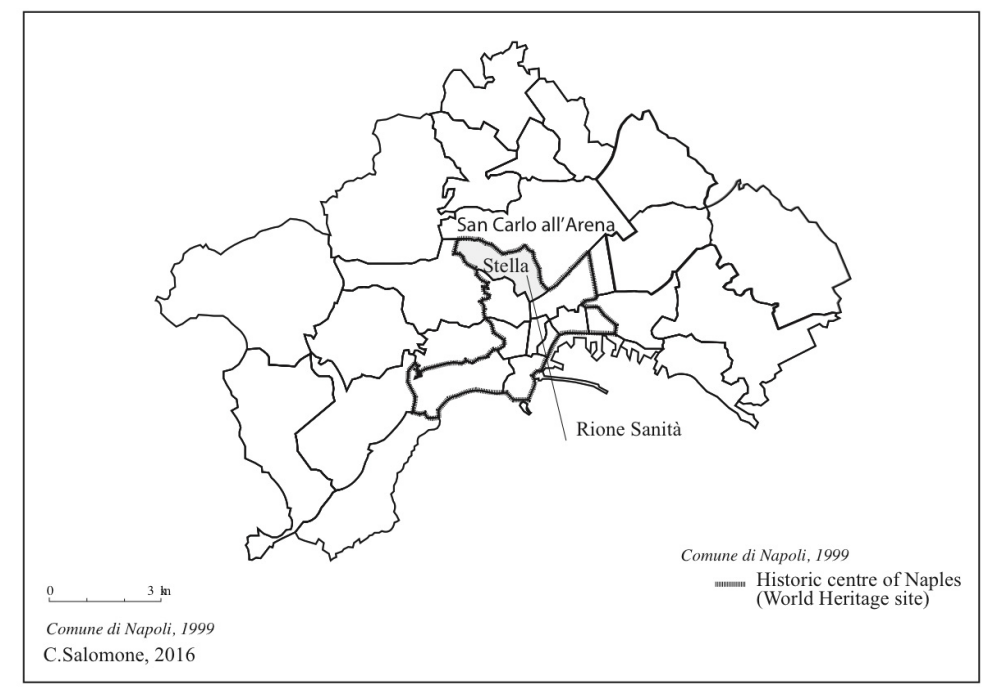

Figure 1: Localisation of the study area. 


\section{Theoretical framework}

The enhancement of the resources pertaining to heritage is an increasingly significant contemporary phenomenon (6). Driven by the dynamics of the "3L" (Leisure, Lore and Landscape), it orients tourism policies. Therefore, the relationship between the world heritage sites and tourism implies a close link with local communities. According to ICOMOS, they play a key role in enhancing, promoting and transmitting heritage. In this sense, heritage covers the notions of material and immaterial heritages, as recognized by societies and transmitted to future generations. The use of the word "heritagization" is more recent. The process implies the conservation of the spirit of place, whilst protecting and recognizing the historical value of the heritage or the site [1]. It can also evoke the passage from a "forgotten" heritage to a "recognized", reclaimed heritage valued as a collective good. Reclaiming ownership from the bottom up contrasts with heritagization by designation [7], typical of the institutional heritage fabric [8]. It involves the local populations and, in particular, the associations which work presently in that field [9]. When the inhabitants are involved, they often have an intimate and familiar relationship with the heritage [10]. This corresponds to a strong territorial anchorage, as a carrier of identity. The latter process presupposes the inventory of the heritage, its identification and its reappropriation by the local population which must become aware of its value. This "discovery" is the prerequisite to its recognition and its reclassification [11]. It can bring enthusiasm and pride to local communities. It then authorises the authentication of heritage status and the need to be exhibited: it now needs to be promoted. It acquires the status of "common good" likely to be transmitted to future generations. Those patrimonial policies accord with participative tourism. This implies the adherence or even the involvement of local populations. However, in popular districts, this is not always applicable [12]. Those policies are also denounced for their social impact. They create a process of gentrification and often generate social change for the inhabitant [13].

\section{Methodology}

This research has been conducted using around 20 interviews with public and private actors (associations, inhabitants, elected representatives and socioprofessionals), as well as secondary sources (municipality and association archives, reports) and by participant observation during various public meetings and guided tours on sites. Our field work, started in 2009, has led to regular visits and a better knowledge of the district. The aim is to share the feelings of actors and inhabitants in order to determine their aspirations. The interviews with locals help identify and penetrate the network of actors and their interrelationships. The analysis will help us assess the modalities of reclaiming the site and encourage an initial monitoring and evaluation of the process. The involvement of the inhabitants will be seen through the degree of commitment of the actors and their territorial anchorage. In order to understand their motivation, 
we must define the main stages of the heritage policies and of the opening to tourism of the district, bearing in mind the local context and the evolution of urban policies. We have chosen a qualitative approach which is more likely to grasp the complexity of a sensitive field and the richness of a human and social reality, which cuts through the official statistics. It is also important to appreciate the social, economic and cultural impacts of heritagization.

\section{Analysis, results and discussions}

This Neapolitan case study reveals several stages in the heritagization process.

\subsection{Patrimonial reinvestment or emergence of a process?}

In the 1980s, the associations of the district testify to the vitality of civil society and a new sensitivity towards the heritage. The initiatives come from the bottom up and are often supported by the Catholic clergy (guided tours of the Fontanelle cemetery from 1986 by the association I-care and around the catacombs of San Gaudioso by the Viviquartiere committee, encouraged by Father Giuseppe Rassello). Local communities take ownership of their heritage spontaneously and without real coordination: they are involved in promoting it and raising awareness and appreciation. Those various initiatives benefit from a favourable context. In the early 1990s, as part of the "Neapolitan Renaissance" the historical centre becomes central to the theatre of heritagization. The Vergini-Sanità area, having long been neglected by urban policies, enjoys the attention of the government as part of the European programs of reclassification (URBAN) [14]. "Monumenti Porte Aperte" (in 1992), a cultural event promoted by the Foundation Napoli, which focuses on the rediscovery of heritage, has a very special impact on the district; it is supported by teachers who promote awareness in their pupils ("la Scuola adotta un monumento") [15].

\subsection{Synergy and associative dynamics around la Paranza}

The creation of la Paranza, a cooperative founded in June 2006 with the support of Father Antonio Loffredo, introduces a new dimension. Private funding encourages the development of the heritage, its presentation (reopening of the paleo-Christian basilica of San Gennaro, lighting and development of the catacombs) and its opening to tourists. This heritage policy is a channel for sociocultural development: the opening of a religious House in 2009, training of guides and synergies created with about fifteen cooperatives of varying competences. Numerous projects with an educational, cultural or social dimension see the light, helping to promote a shift in attitude and a cultural opening. In December 2014, the creation of the foundation of the Community San Gennaro constitutes a turning point: its objective is to promote a change from the bottom to reinforce the emergent synergy between all the actors. It is funded by private external sources and a network of local companies. 


\subsection{Moving towards a district united around its development?}

In the wake of these developments, new associations become involved in the reappropriation of the district [16]. They reveal a little-known heritage and encourage its protection and awareness. Celanapoli, created in 2011 by an archaeology enthusiast, allows the rediscovery of a completely forgotten heritage and encourages its development for tourism (the Hellenistic funerary hypogeum of the via Antesaecula). Others publicize the heritage (maps, tourist guides, conferences organised with the University to obtain European funding) and promote the opening of the district to tourism. The associations then organise their actions around informal networks, such as la rete Sanità, supported by Father Alex Zanotelli. It rallies the parties involved around economic, social and everyday questions and changes the patrimonial claim to an investment of identity. In October 2015, it suggests implementing responsible and participative tourism relying on the non-profit sector anchored in the territory (figure 2).

\subsection{A conflictual heritagization?}

But, heritagization can crystallize conflicts on a particular aspect of heritage, such as in the case of the Fontenelle cemetery. This site, whose opening is still uncertain, is a battleground. Its occupation in May 2010 by the inhabitants and the associations forces the authorities to legitimate the claims and make its opening official. The management of the site remains undecided. It intensifies the associative rivalries, as the site has many visitors and the economic stakes are considerable [17]. In 2014, the local authority involves the association IRISFontanelle and the priest who initiated the guided tours, in the creation of a technical commission responsible for finding a lasting solution. The guided tours which are led by young people from the district and consolidate their attachment to the place of origin of their parents, continue to respect the authenticity and sacredness of the site. They encourage them to have a deeper cultural awareness of the place.

\subsection{Initial assessment}

The district is a true laboratory of heritagization from the bottom up. Many facets and a plurality of actors explain the contrasts apparent in the process. The revival of the heritage and the opening of the district to tourism have led to a growing number of tourists visiting the site and an expansion of tourist accommodation. The district has been reincorporated into the official tourist routes and its image is rejuvenated in a range of contexts (tourist guides, institutional websites). Patrimonial mobilisation is a channel of local development (over a hundred jobs created), even if it remains difficult to evaluate. It relies on the dynamism of local associations and the support of the locals. This mobilisation fosters a shift in attitude, creating a desire to integrate into the networks and a willingness to open to the outside world. The attachment to one's heritage has created a new pattern of intergenerational transmission. Nonetheless, the development of tourism remains fragile, as a result of delays in 


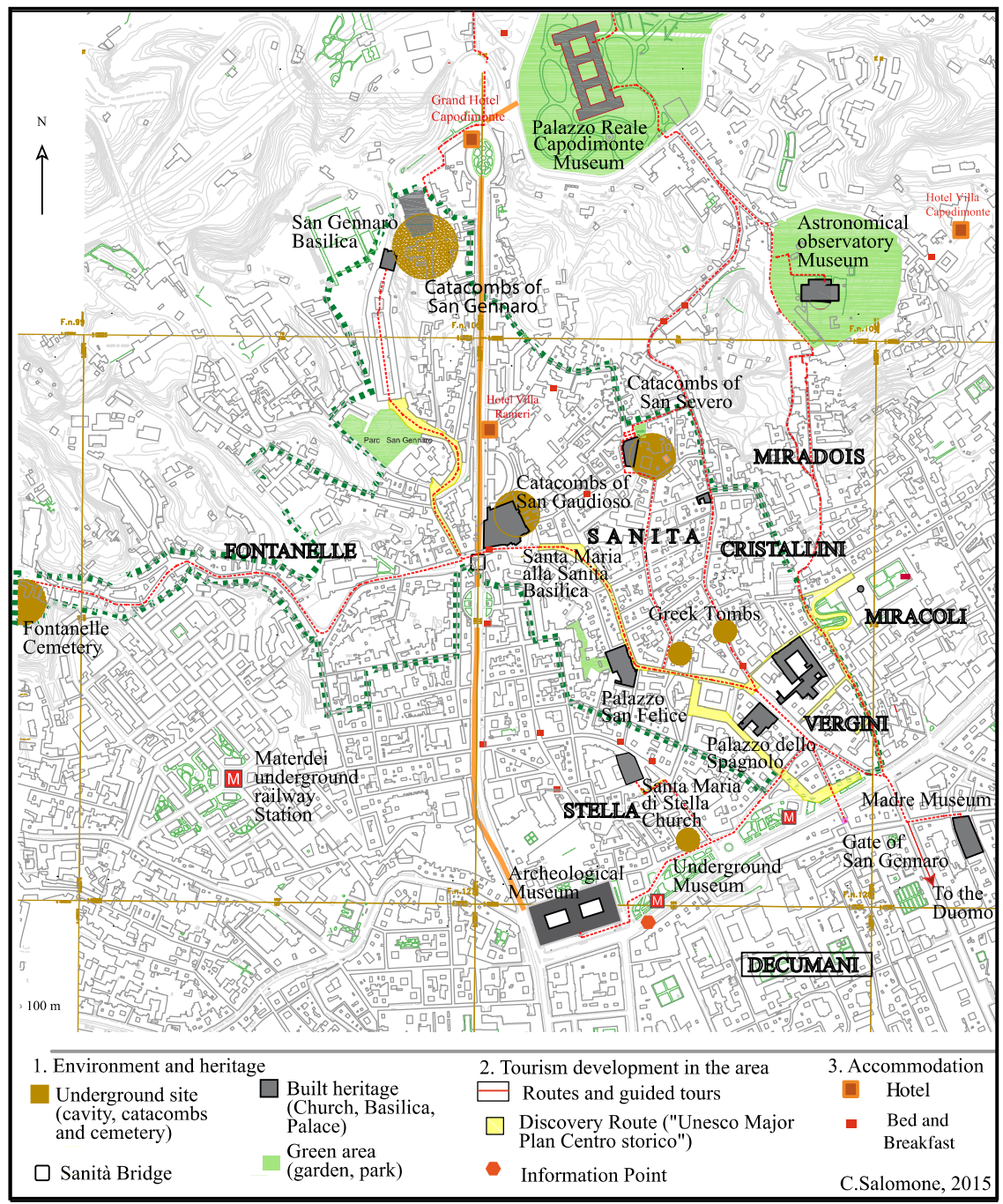

Figure 2: Heritage and tourism implementation in the Sanità district.

terms of accessibility, equipment and quality of life. Is the population, which has to deal with everyday problems, really sensitive to reviving the heritage and tourism, except for some very committed associative actors? For some of the shopkeepers surveyed, the locals are far removed from those preoccupations or simply, indifferent, even if they have regained some pride. Those who get involved with guided tours are outsiders to the district, local residents, Italians, but rarely foreign tourists. Some observers fear that those changes may lead to a process of gentrification and the loss of identity. 
"The problem is not tourism, it is not because tourists come, the problem is that the rich, especially those from Naples and also from outside, once they have understood the potentialities of this district, they start to buy and to scare away the population in order to turn it into an "upmarket district" (interview with father Alex Zanotelli on the 21st July 2015).

The question is to know whether heritagization implies risks for the district and its identity.

\section{Final considerations}

This Neapolitan example testifies to the complexity of the heritagization process from the bottom up and the plurality of actors. The associative dynamics allow the (re)discovery of sites or places according to different modalities. They testify to deep changes in the opening of the district to the outside world, the integration into networks and a shift in attitude. Heritage is now perceived by everyone as an economic resource. For some of the actors, patrimonial mobilisation also has a political dimension, indicative of their intervention in the public sphere, whilst also having a strong sense of identity. Beyond the consensus built around the heritagization process, conflicts can arise in terms of the management of a site, such as the Fontanelle cemetery. The question is about the relationship with the authorities. The main actors have established unequal relationships. The inefficiency of the policies implemented and the limited funding allocated to the reclassification of the district maintain a feeling of suspicion and scepticism. To what extent can this process of heritagization from the bottom up, trigger an effect on the urban policies to be put in place? Heritagization is therefore seen as a permanent tension between remembering and forgetting the sites, reclaiming ownership and conserving the heritage, what local residents say and what official discourses proclaim.

\section{References}

[1] ICOMOS, Symposium Icomos Canada 2008.

[2] Veschambre, V. (2007). "Patrimoine: un objet révélateur des évolutions de la géographie et de sa place dans les sciences sociales", Annales de géographie, 4, n 656, pp. 361-381.

[3] Comune di Napoli (2002). Rapporto finale di esecuzione, URBAN.

[4] Comune di Napoli (2011). Profilo di Comunità, Municipalità 3 - Distretto 29, Stella - San Carlo all'Arena 2010-2012, A. Guida Editore.

[5] Salomone, C. (2013). "Patrimoine et valorisation touristique au cour d'une tentative de requalification d'un quartier: le cas de la Sanità à Naples", 50e Colloque ASRDLF, Culture, Patrimoine et savoirs, Mons 8-11 juillet.

[6] Graham, B., Ashworth, G.J. \& Turnbridge, J.E. (2000). A geography of heritage: Power, culture and economy. London: Hodder Arnold.

[7] Rautenberg, M. (2003). La rupture patrimoniale. Paris, Bernin, À la croisée. 
[8] Heinich, N. (2009). La fabrique du patrimoine. De la cathédrale à la petite cuillère, Editions de la Maison des sciences de l'homme, Paris.

[9] Glevarec, H. \& Saez, G. (2002). Le patrimoine saisi par les associations, Paris, La Documentation française.

[10] Jacquot, S. (2015). "Politiques de valorisation patrimoniale et figuration des habitants en banlieue parisienne (Plaine Commune)", EchoGéo, 33.

[11] Damien M.-M. \& Dorvillé C. (2011). Le patrimoine de nos régions: ruine ou richesse future? Exemples de dynamiques territoriales, Paris, L'Harmattan.

[12] Veschambre, V. (2013). Défense de l'habitat social versus "patrimoine": deux registres d'argumentation contre les démolitions qui ne convergent pas. In Desponds D. (dir.), Les habitants, acteurs de la rénovation urbaine? Rennes, PUR, pp. 46-61.

[13] Semmoud, N. (2005). "Valorisation patrimoniale et changement social: un pléonasme?” In Gravari-Barbas M. (dir.), Habiter le patrimoine: enjeux approches - discours. Rennes, Presses universitaires de Rennes, pp. $265-$ 280.

[14] Comune di Napoli (1997). Programma URBAN, UE, Quartieri Spagnoli, Rione Sanità.

[15] Palestino, Maria Federica (2003). MiraNapoli, la costruzione dell'immagine urbana negli anni 90, Napoli, Clean edizioni, $111 \mathrm{p}$.

[16] Salomone, C. (2014). Perception et représentations d'une destination touristique: le cas de Naples, thèse de doctorat en géographie sous la direction de Marie-Madeleine Damien, Lille, Université des Sciences et Technologies de Lille I.

[17] Salomone, C. (2016). “ La Naples souterraine et le tourisme de l'insolite où comment réinventer une destination touristique traditionnelle?", Téoros, Presses de l'Université de Québec, UQAM.

[18] Buccaro, A. (1991). Il Borgo dei Vergini. Storia et struttura di un ambito urbano, CUEN Editrice. 